\title{
Innovations Induce Asymmetric Employment Movements
}

\author{
Thomas Zwick* \\ Zentrum für Europäische Wirtschaftsforschung, Mannheim
}

June 1999

\begin{abstract}
This paper provides a labour supply explanation to the observation that in Germany employment changes are asymmetric during the business cycle. Employment increases are slower, because the reservation wage of workers increases in times of job uncertainty. Workers are afraid in those periods of losing their sunk and necessary human capital investments. They weigh the risks and benefits of investing in human capital with their certain outside option when they decide about staying in the labour market. Human capital investments are sunk and necessary, because firms need new skills while older skills get obsolete at a constant rate. Skill obsolescence is induced by innovations.
\end{abstract}

JEL-Codes: J22, J24, O30

\footnotetext{
*I want to thank Herbert Buscher and Wolfgang Franz for useful comments.
} 


\section{Nontechnical Summary}

Employment increases in Germany are slower than employment decreases. In the literature several labour demand reasons for this asymmetry are presented like the insider-outsider theory, shortage of physical capital and human capital demand. This paper provides an additional labour supply explanation to the employment asymmetry observation.

Employment increases are slower, because the wage that makes workers indifferent between working or not increases in times of job uncertainty. Workers need a risk mark-up in order to stay in the labour market in these periods. They have to be compensated for the risk to loose their sunk investment costs in human capital. Investments in human capital are necessary in this model in every period, regardless of the situation in the business cycle, because we observe that innovations are introduced regardless of the business cycle with a regular pace. In addition, innovations usually require new skills from the workforce in order to be implemented. These skills required by innovations frequently are rather specific. The specificity may come from two sides. Either the required skills are productive only in the few firms/sectors that introduce these innovations or the new skills decay quickly and can be used only for a short time period. When the employment prospects in an adequate job for the skills acquired in the near future are weak, the expected pay-off of these human capital investments are low. Here, the unemployment benefit may be more attractive than the uncertain earnings minus the sunk investment costs. Human capital investments are sunk, because they do not generate any pay-off when no adequate job is found. The wage in an inadequate job or the unemployment benefit usually is not increased by the human capital investment.

In a first step, a standard micro-founded labour market model is developed without taking into consideration human capital investment. Here, employment fluctuates symmetrical over the business cycle. If we introduce human capital investments in this model, however, employment reacts asymmetric on aggregate shocks, because the workers demand an uncertainty wage bonus.

In several extensions, it is shown that the results are robust with respect to changes in the assumptions. In the first extension, the Neo-Keynesian assumption of fixed real wages in the short run is introduced. A second extension specifies the expectations function of the workers and a third extension argues that also allowing for different regional or educational unemployment rates does not change the results. 


\section{Introduction}

Employment changes are asymmetric during the economic cycle in Germany. We observe swifter declines than increases in employment. While employment decreases with an average yearly rate of 0.053 , employment recovery is inert in a boom phase and increases significantly slower with a rate of $0.039{ }^{1}$ This pattern is well known (compare for example Caballero and Hammour 1994, Franz 1990 or Blanchard and Summers 1986) and several explanations can be found in the literature. Blanchard and Summers (1986) mention three salient reasons why shocks that cause unemployment might have long-term effects: shortage of physical capital, insider-outsider effects and human capital.

Insider-Outsider theories predict that insiders use the increased economic activity after a depression that reduced the number of insiders for wage increases (see, for example, Lindbeck and Snower 1996). This leads to less additional employment and in extreme cases to complete hysteresis during the following up-swing. Direct evidence for insider-outsider forces on wage setting and employment is weak, however, confer Franz (1990) or Winter-Ebmer (1992). A further reason for employment asymmetries may be scrapping of capital in slack periods (see, for example, Winter-Ebmer 1992, or Caballero and Hammour 1994) or an increase of capacity utilization after a depression at the same level of employment. These theories need a reference to wage bargaining behaviour and capital adjustment costs, however, in order to be able to explain the observed employment asymmetries, and therefore the pure effect of capital on the asymmetries is unclear. This paper is concerned with the third argument-human capital formation - and treats capital as exogeneous.

Human capital formation as a reason for hysteresis in unemployment has attracted less interest than insider-outsider and capital shortage models. Most models linking employment or unemployment changes with human capital theory use the argument of deterioration of human capital during unemployment spells. It is argued that individuals who have been unemployed for a long period of time do not have the required productivity any more, because they did not have the opportunity to update their skills by learning-by-doing or training on the job. Updating of skills is necessary, however, because innovations require continuously new skills. In addition, the unemployed lost self-confidence or are not used to strict working morale any more (see, for example, Hargreaves Heap 1980, Blanchard and Summers 1986, Möller 1990 or Goldsmith and Darity 1992). This means that the unemployed lose their attractiveness for firms because technological changes induce outdating of their skills or the experience of unemployment undermines their working morale.

This paper introduces a new argument by focusing on incentives of workers to invest in human capital. In this paper employment asymmetries are created

\footnotetext{
${ }^{1}$ See appendix for a description of the regression and its statistical properties.
} 
therefore by the labour supply decision instead of labour demand. The main argument is that workers have a higher reservation wage in times of employment uncertainty. The higher wage forms an incentive to sink costs in human capital investments that are necessary for production, but have a positive effect on labour productivity only during a limited time period. These necessary human capital investments are caused for example by innovations. Innovations in products or the organizational structure of a firm usually have the effect that certain skills are not needed any more. In addition innovations require new skills of the workers and continuous learning and training (see, for example, Acemoglu and Pischke (1999). The literature usually assumes that innovations a firm has developped or can readily buy on the market can be installed costlessly within the firm. ${ }^{2}$ If we take the effects of innovations on human capital (obsolence of older skills and necessity to innovate in new skills) into account, however, we can derive an additional argument for the observed employment asymmetries in a standard labour market model.

Innovations occur on a macroeconomic level with a steady pace during the business cycle (compare for example Caballero and Hammour 1994) and therefore innovations demand continuous adaption efforts from the workers in order to obtain the necessary skills to handle the innovations, compare e.g. Hargreaves Heap (1980) p. 613. Those new skills required by the introduction of an innovation in the firm are not necessarily specific in the sense of Becker (1975), but the fact that they get obsolete after some time leads to the same characteristics from the point of view of the employee: Either the employee finds or keeps an adequate job for the skills acquired and earns the return associated with the investment within a certain period or the sunk investment costs are lost. Investment costs are sunk, because they do not increase the productivity in a job found at another firm (this firm may have introduced a different innovation) or a job found after a while such that the skilled required by the previous innovation are already obsolete. When the worker gets unemployed, the investment does not increase unemployment benefits.

A second complication of human capital investments arises from the point of view of the workers when firms innovate: human capital investments are made under the uncertainty, if the current position can be held or an appropriate job can be found quickly. As workers only invest in human capital if the expected returns are higher than the associated costs, the willingness to invest decreases in times of employment uncertainty because this reduces the expected returns to human capital investments. This argument applies for workers and job applicants alike, because human capital investments are required for employees and those who would like to enter the labour market.

2 "The conventional industrial organization literature on $\mathrm{R} \& \mathrm{D}$ competition, (...), assumes that the process of innovation is fricitonless and in particular that firms face no costs in acquiring amy new skills they need once they have innovated." David Ulph (1996):85. 
Summing up, we need three basic assumptions in order to obtain employment asymmetries:

1. Innovations force workers to invest continuously in new human capital, while old human capital gets obsolete.

2. The acquisition of the necessary new skills is costly for the workers and includes sunk costs: costs that can not be recovered when the employment relation is terminated.

3. Workers form expectations about the probability that they loose their jobs based on employment movement information from the previous period.

This paper demonstrates that innovations induce asymmetric employment movements. First, a standard labour market model without human capital formation is developed. Here, the employment changes are symmetric over the business cycle. If innovations are introduced into the standard model, we find asymmetries in the reaction of employment on aggregate demand shocks.

\section{A Simple Labour Market Model}

In this chapter a simple labour market model with explicit micro-foundations is developed without taking into account human capital formation. The profit function of the firm is simplified to the following:

$$
\pi=\theta g(l)-w l,
$$

with $g^{\prime}(\cdot)>0, g^{\prime \prime}(\cdot) \leq 0$, while $l$ is the number of workers demanded by the firm, $w$ is nominal wage, and $\theta$ the goods price indicating the state of the economy (e.g. goods demand, government expenditures, exports etc.). $\theta$ is distributed uniformly with upper and lower bounds $\theta \in[\underline{\theta} ; \bar{\theta}]$ with $\underline{\theta} ; \bar{\theta} \in R^{+}$. There are no rigidities like menu costs or hiring/firing costs. Labour demand of the firm is given by the condition that the marginal revenue product of labour equals the nominal wage $\theta g^{\prime}=w$. This results in a falling labour demand curve, $D$, which is depicted linearly for convenience in Figure 1. In other words, it is assumed that $g^{\prime}=a l$ with $a$ constant.

Every worker can decide to offer his or her labour power or not, therefore there is no decision between consumption and leisure time. A worker supplies labour if the wage is higher than her or his reservation wage. The reservation wage depends on labour disutility that differs between individuals and the outside option. When the wage is lower than the reservation wage, the worker voluntarily stays out of the labour market. At the reservation wage the worker is indifferent between working or not, that is, the expected surplus when working has to be equal to the certain unemployment benefit $\bar{s}$. The easiest formulation for workers' 
utility functions is to reduce the argument to monetary units and assume riskneutrality. When accepting a job, the worker has to take into account that he or she might lose or quit the job during the period, because the state of the economy $\theta$ deteriorates and labour demand of the firm therefore is reduced. When labour demand decreases, wages also decrease instantaneously in order to clear the labour market. It is therefore in the logic of the model that the agent on the shorter market side can renegotiate wages after a demand shock and dictate the new market-clearing wage. ${ }^{3}$ When the wage decreases, workers with high reservation wages decide to quit their jobs.

When labour demand $l_{t}$ is larger than labour supply $n_{t-1}$, all employed workers keep their jobs with certainty and their individual expected earnings are the market wage $w_{t}$. When $l_{t-1}<n_{t-1}$, workers lose their jobs randomly and their expected earnings are the market wage $w_{t}$ with probability $\frac{l_{t}}{n_{t-1}}$, while they earn the outside option $\bar{s}$ otherwise. The workers do not know the realization of $\theta$ and therefore $\frac{l_{t}}{n_{t-1}}$ when signing the labour contract. As a consequence, they have to form expectations $E\left(\right.$.) about labour demanded in period $l_{t}$ after the shock has occurred relative to labour supply $n_{t-1}$ at the beginning of the period. We assume that expectations $E\left(\frac{l_{t}}{n_{t-1}}\right)=f\left(\frac{l_{t-1}}{n_{t-2}}\right) \in[0,1]$, with $E\left(\frac{l_{t}}{n_{t-1}}\right)=1$ if $l_{t-1} \geq n_{t-2}$ and $E\left(\frac{l_{t}}{n_{t-1}}\right)<1$ if $l_{t-1}<n_{t-2}$ because the individual possibility to be employed may not be higher than one for an individual. One motivation for this assumption is that deviations of real economic aggregates from the trend are serially correlated (compare e.g. Pissarides (1992) p. 1371) and therefore lay-offs occur in waves. Employment changes in Germany have the same direction for several quarters. If in one quarter employment decreases, it is save to assume that employment will decrease also in the following year or quarter. The average decrease in employment takes $12 \frac{1}{4}$ quarters, while the average increase in employment takes $22 \frac{1}{4}$ quarters in Germany.

The worker knows how many workers $n_{t-1}$ applied for a job in the previous period $t-1$. As long as there is no shock, labour supply is not changed. Worker $i$ has the following individual expected utility $s_{t}^{i}$ in period $t$ depending on his/her disutility of work $h_{i}$ :

$$
s_{t}^{i}=E\left(\frac{l_{t}}{n_{t-1}}\right) w_{t}+E\left(\frac{n_{t-1}-l_{t}}{n_{t-1}}\right) \bar{s}-E\left(\frac{l_{t}}{n_{t-1}}\right) h_{i} .
$$

If we set the expected individual (monetary) utility of the worker equal to the time-invariant outside option $s_{t}^{i}=\bar{s}$, we obtain the following expression for the reservation wage $\widehat{w}^{i}$ which is at least necessary to give a worker an incentive to work:

$$
\widehat{w}^{i}=\bar{s}+h_{i}
$$

\footnotetext{
${ }^{3}$ The assumption of flexible wages is relaxed below in a Neo-Keynesian setting where wages are fixed in the short run.
} 
That is, when $w_{t}>\widehat{w}^{i}$, labour is supplied by individual $i$. Therefore it is clear that the probability to be unemployed and the expectations of the workers about this probability do not affect the reservation wage. The time-invariant aggregate labour supply only depends on the distribution of the monetary disutilities to work and the outside option. At the market wage, the marginal employed worker with the highest work disutility is indifferent between working and being unemployed, while all infra-marginal workers enjoy a monetary utility above their outside option. When the wage decreases, workers with high reservation wages leave the firm. Therefore, we have an increasing supply function of labour $S$. The function $S$ is depicted linearly in Figure 1 for convenience (i.e. it is a linear function of the number of workers while the number of workers is continuous in order to avoid integer problems. In addition, $h_{0}$ is set to zero).

Let us look at a short-run equilibrium, where capital stock, price, state of technology and wealth are treated as given. Neither the firm nor the workers have market power and all agents are therefore incapable to push the other side from their wage reaction function $D$ or $S$. Market clearing establishes a common wage paid to employed workers, and existing underemployment is considered to be frictional and voluntary. ${ }^{4}$

The aggregate labour market equilibrium is in period 1 at point $e_{1}$ in Figure 1 with a market clearing wage $w_{1}$. Labour demand shifts from $D_{1}$ to $D_{2}$ when the economy experiences an exogeneous negative aggregate shock $\left(\theta_{1}\right.$ decreases to $\theta_{2}$ ). Assuming that the firm can instantaneously renegotiate the wage to $w_{2}$, workers voluntarily leave the labour market. The negative supply shock leads to a lower employment level $e_{2}$. In the simple labour market model, the reduction in employment has no effect on the reservation wage of the workers. In addition, it does not matter whether in period 0 the labour market equilibrium was at $e_{1}$ or for example $e_{0}$.

If we assume that there is a positive aggregate shock, i.e. $\theta_{2}$ increases to $\theta_{1}$, we obtain a symmetric positive reaction in wages and employment. In this case, wages are also renegotiated immediately and increase such that enough new workers are attracted in order to satisfy the increased labour demand. Therefore employment changes are symmetric over the business cycle.

\footnotetext{
${ }^{4}$ Compare Goldsmith and Darity (1992), p. 450.
} 


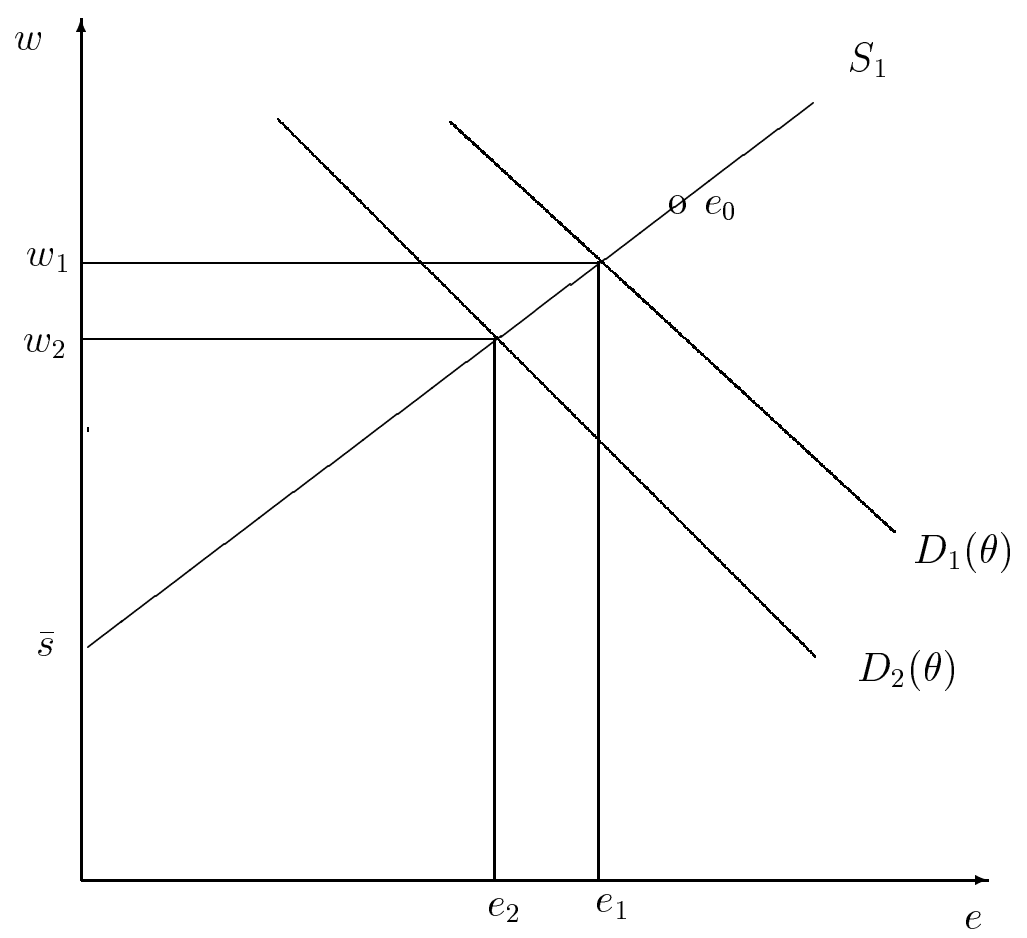

Figure 1: The Aggregate Labour Market

\section{Innovations Demand Human Capital Invest- ments}

Now human capital formation is introduced in the model. Innovations demand costly human capital investments in every period. These new skills are acquired by training. Innovations can therefore not costlessly be implemented and human capital acquired in these training courses decays completely after one period.

Skills have to be up-dated in order to adapt to innovations that introduce new and different products and production processes evolving with an exogeneously given and constant rate. Innovations are introduced continuously during the business cycle and therefore workers have to invest in every period independently of $\theta$. For simplicity it is assumed that this investment in topical or specific skills is necessary at the beginning of every period and a fixed amount $c$. In the tradition of Ulph (1996) it is assumed that firms have to innovate in order to keep their market share and that competition reduces all possibilities to earn a rent higher than the investment costs from innovations. Therefore a worker who does not have the new skills is not eligible to work in the firm while the production function (1) is unchanged for simplicity. 
In the beginning of every period, all workers who want to join the work force have to invest $c$ in skills update. At that moment workers know the equilibrium wage and labour supply. They do not know, however, the size and direction of an aggregate demand shock on the economy that might occur during the period when the skills are valid. Therefore expectations about labour demand have to be formed like in the previous model.

Workers have to pay for their sunk investments in skills updates themselves. ${ }^{5}$ The ex-post surplus of the workers who invest in human capital in order to have the possibility to enter or stay in the labour market is:

$$
\begin{aligned}
s_{t}^{i}=w_{t}-\widehat{h}^{i}-c, & & \text { if employed, and } \\
s_{t}^{i}=\bar{s}-c, & & \text { if unemployed. }
\end{aligned}
$$

The employed workers earn the market wage $w_{t}$ and have to deduct their disutility of work and investment costs in human capital. In order to be able to compare the model with human capital investments with the simple labour market model, we assume a different scaling of the monetary disutility of work. The re-scaling is performed such that with no change in employment both models are equal, i.e. the disutility of work is now $\widehat{h}^{i}=h^{i}-c$. Therefore labour supply is unchanged if all workers expect to keep their jobs.

The expected utility of individual $i$ in period $t$ is now:

$$
s_{t}^{i}=E\left(\frac{l_{t}}{n_{t-1}}\right) w_{t}+E\left(1-\frac{l_{t}}{n_{t-1}}\right) \bar{s}-E\left(\frac{l_{t}}{n_{t-1}}\right) \widehat{h}_{t}^{i}-c,
$$

or:

$$
s_{t}^{i}=E\left(\frac{l_{t}}{n_{t-1}}\right) w_{t}+E\left(1-\frac{l_{t}}{n_{t-1}}\right) \bar{s}-E\left(\frac{l_{t}}{n_{t-1}}\right) h_{i}-E\left(1-\frac{l_{t}}{n_{t-1}}\right) c .
$$

The utility $s_{t}^{i}$ of accepting a job depends on the expected chance to stay employed in period $t$.

The reservation wage of individual $i$ is:

$$
\widehat{w}_{t}^{i}=\bar{s}+h_{i}+\frac{1}{E\left(\frac{l_{t}}{n_{t-1}}\right)} c .
$$

The wage that is necessary to attract a certain number of workers is higher in period $t$ than in equation (2) if $E\left(\frac{l_{t}}{n_{t-1}}\right)$ is smaller than one, i.e. if the worker expects that labour demand in the topical period is smaller than labour supply in the previous period, or if the worker expects that there occurs a negative aggregate shock. When workers do not expect a reduction in labour demand, the reservation wage is the same as in the reference model.

\footnotetext{
${ }^{5}$ Even if the firm bears the actual costs of a trainee programme, workers have to invest their time and effort. In addition it may be cumbersome for workers to adapt to changes.
} 
It is assumed that workers expect an employment decrease in this period again if employment decreased in the previous period, i.e. $E\left(\frac{l_{t}}{n_{t-1}}\right)<1$ if $l_{t-1}<n_{t-2}$.

The model with human capital up-date and training costs can be depicted like in Figure 2:

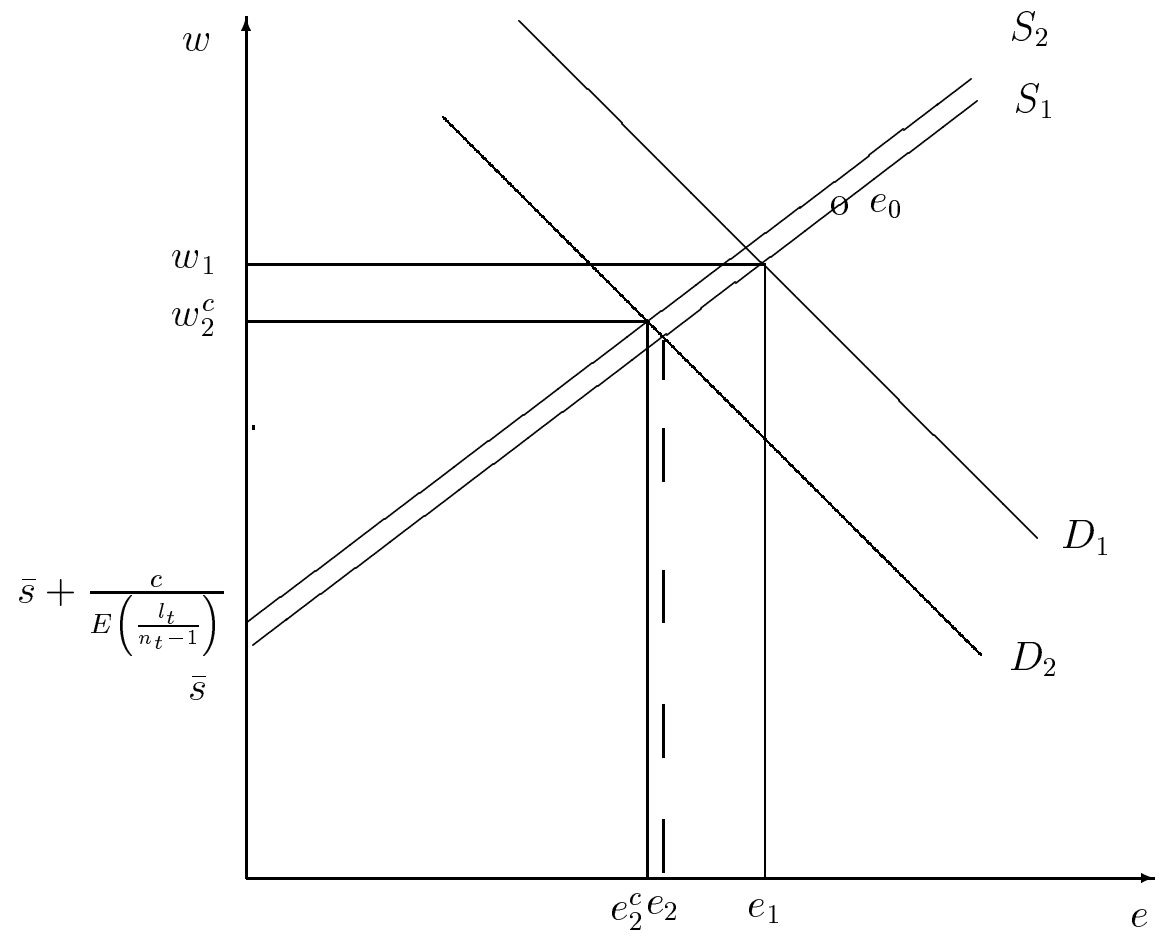

Figure 2: The Aggregate Labour Market with Human Capital Formation

Consider the situation that in period zero a negative aggregate demand shock induced a reduction in employment from $e_{0}$ to $e_{1}$. As a consequence, workers expect a further decline in employment and $E\left(\frac{l_{1}}{n_{0}}\right)<1$. Therefore the reservation wage increases and labour supply decreases from $S_{1}$ to $S_{2}$ in Figure 2, because workers charge a risk mark-up. ${ }^{6}$ If we compare the results of the labour market with and without innovations, we see that an identical negative aggregate shock from $\theta_{1}$ to $\theta_{2}$ induces the lower market clearing employment level $e_{2}^{c}$ instead of $e_{2}$ if we introduce innovations. A reduction in employment leads to a stronger employment decline in the following period.

A positive shock on $\theta$ in the wake of a negative shock also leads to a lower employment increase than in the model without human capital formation. Consider the case with a positive aggregate demand shock after a period with an employment decline. The new employment equilibrium is at the labour supply

\footnotetext{
${ }^{6}$ Blanchflower also deducts this result in his perfect competition model without referring to the problems of sunk costs: "Fear of unemployment has to be compensated, like any other disutility, by greater remuneration." (Blanchflower 1991 p. 484).
} 
curve $S_{2}$ instead of $S_{1}$ and therefore at a lower employment level for all levels of labour supply. This establishes our result that employment declines are stronger and employment increases weaker after a period of employment decline. The employment movements are the same as in the reference labour market when employment was unchanged or increased in the previous period. Therefore the introduction of human capital investments caused by innovations leads to asymmetric employment reactions during the business cycle.

If the output price is unchanged in period 2, the employment increases to $e_{2}$ at the beginning of period 3 , because the perceived risk is reduced. Then the reservation wage equals $\bar{s}+h_{i}$ again in period 3 . Therefore the asymmetric employment effect of human capital investment is only of a temporary nature and labour supply shifts back to $S_{1}$ after one period if no new adverse employment shocks occur.

\subsection{Extensions}

The argument given in this paper is general and may be applied to several situations. In order to validate the hypothesis that workers ask for a risk wage mark-up in times of employment uncertainty when they have to sink costs in order to invest in specific human capital, several assumptions may be further specified. In order to show that the basic and general model easily may be modified in order to introduce facts encountered empirically, several extensions are presented here.

- Neo-Keynesian Labour Market

The assumption of immediately clearing labour markets and free floating wages is certainly not always realistic. We demonstrate now that the results are virtually unchanged if we assume instead that the wage is fixed during one period. According to standard Neo-Keynesian labour market models, it is therefore assumed that the wages are set market-clearing at the beginning of the period and may be changed only at the beginning of the next period.

The sequence of events in the model with human capital formation can be illustrated in the following diagram:

1st period 2nd period

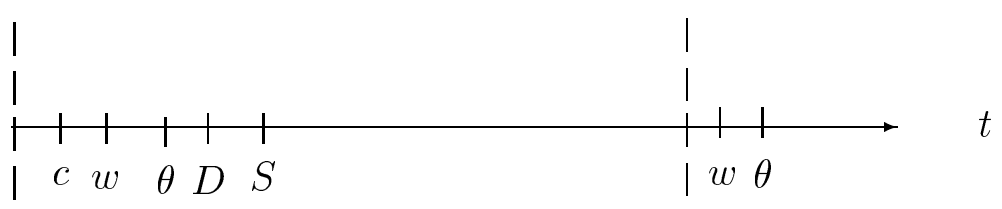

Diagram 1: Sequence of Events when Wages are fixed 
Before the wage adapts and workers can apply for a job or extend their employment contract, all workers who want to join the work force have to invest $c$ in skills update. At that moment workers know the market clearing wage. They do not know, however, if there is a shock on the economy during this period that induces a reaction of labour demand $D$. The rigidity of wages leads to involuntary unemployment in the wake of an adverse shock. Labour demand shifts to the left, while labour supply is unchanged at a given wage. Therefore, the number of unemployed after an adverse shock is, other things equal, higher than in the model with instantaneous wage changes. The workers form expectations about the size of the employment reductions again and their reservation wage is equal to equation (3). The wage $w_{t}$ does not adapt during the period and therefore labour demand shifts horizontally from labour demand curve $D_{t-1}$ to $D_{t-1}$. Workers assume that the reduction in employment in this period is related to that in the last period, because employment reductions occur in waves. Therefore workers ask for a higher risk mark-up than in the case with flexible wages, because the employment fluctuations are higher at given adverse shocks. In addition, it is clear that the reservation wage equals (2) in the model without human capital investments and therefore the model without human capital investments is still symmetric when wages are rigid.

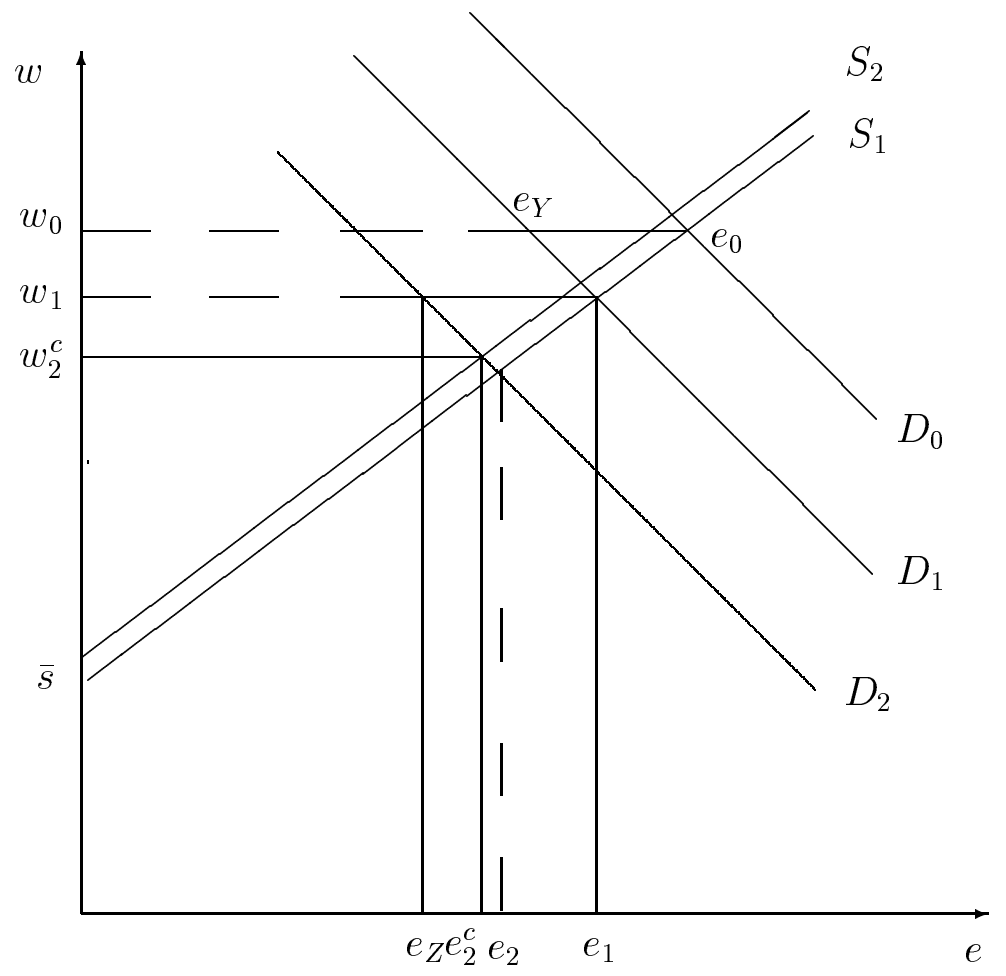

Figure 3: Labour Market with Fixed Wages and Human Capital Formation 
Consider the situation that in period zero a negative aggregate demand shock induced involuntary unemployment $e_{0}-e_{Y}$. As a consequence, labour supply decreases to $S_{2}$ and workers charge a risk mark-up. A negative aggregate shock from $\theta_{1}$ to $\theta_{2}$ incurs involuntary unemployment $e_{1}-e_{Z}$. The market clearing employment level will be $e_{2}^{c}$ instead $e_{2}$ in the beginning of the next period. Labour supply is shifted from $S_{1}$ to $S_{2}$ because workers expect the further decline in employment after the experience of involuntary unemployment in period 0 . The asymmetry is therefore also obtained if wages are rigid in the short run.

\section{- Expectations}

Until now, we did not specify the expectation formation of the workers about labour demand. We only assumed that the workers expect a reduction in employment in the next period when in this period there was a reduction in employment, because employment reductions come in waves. Frequently, adaptive expectations

are assumed, for example $E\left(\frac{l_{t}}{n_{t-1}}\right)=\lambda \frac{l_{t-1}}{n_{t-2}}$. A high $\lambda$ implies that workers think that the decrease in employment is strongly related between both periods and that the relative number of workers fired is comparable to that in the previous period. $\lambda$ of zero implies that workers do not expect $\theta$ to decrease further.

- Regional or Skill-Specific Unemployment Rate

The incidence of unemployment is diverse with respect to regions, tenure and educational levels. As workers are not perfectly mobile and cannot replace their educational level, tenure or qualifications at will, they frequently will not consider the aggregate changes in employment as an indicator for their personal risk to get unemployed. Instead, workers base their expectations on the regional rate or the rate for workers with a comparable tenure or educational level. Nevertheless the asymmetry results are also obtained on the macroeconomic level if only some educational groups or workers in certain regions were exposed to employment risk in the period and innovations require that all workers invest regularly in human capital.

\section{Limitations}

This paper shows that innovations that cause a necessity to invest in human capital and obsolescence of previous skills lead to an asymmetry in the cyclical movements of employment. Workers ask for a risk-mark up when they perceive a risk to lose their jobs. This may partly explain the asymmetries in the development of employment observed in Germany where the employment growth rates are significantly lower than employment decline rates. The paper does not take into account several factors that may be relevant empirically, however. For 
example we do not account for different forms of wage bargaining, but it is assumed that the firm is the residual claimant by setting the utility of the marginal worker equal to his or her outside option. It is frequently observed that firms grant part of the rent created by workers to workers in "good times" according to fairness or gift-exchange considerations. In "bad times" these bonuses may be reduced however according to the reduced profits or a weaker bargaining position of the workers. In addition, unemployment has no emotional or social value in this model. In reality, people tend to regard unemployment as a bad in addition to the decline of income associated with it. When happiness is negatively affected by unemployment spells (compare for example Clark and Oswald 1994), workers are more willing to comply to company needs especially in times of employment uncertainty. Both factors may conceal the risk mark-up effect derived in this paper in an empirical investigation. Therefore these factors have to be taken into account by analyzing the investment behaviour of workers in specific or time-dependent skills.

\section{Appendix: Empirical Evidence}

In order to test, whether employment growth is symmetric during the business cycle in (West-)Germany, the employment growth rate is separately calculated for periods of employment growth and for periods of decreases in employment. First, the logarithm of quarterly employment data are seasonally adjusted by the Census X-11 method, then the entire sample is split into two sub-samples with positive and with negative employment changes. Finally, the growth rate of employment GROWTH is regressed by ordinary least squares on two dummy variables $U P$ (for positive employment growth) and $D O W N$ (for negative employment growth) in order to demonstrate that the employment growth rate in

periods with employment increases is larger than in periods with employment reductions.

$$
G R O W T H=\alpha_{1} U P+\alpha_{2} D O W N+\varepsilon
$$

The coefficients are presented in the Table 1 below .

Data Source: DIW Vierteljährliche Volkswirtschaftliche Gesamtrechnung.

We chose the West-German data series in order to avoid biased effects resulting from the structural decline in East-Germany after the re-unification. If we include the employment movements in East-Germany, however, the results are roughly the same. 


\begin{tabular}{|c|c|c|c|c|}
\hline \multicolumn{2}{|c|}{ DependentVariable: } & \multicolumn{3}{|l|}{ GROWTH } \\
\hline \multicolumn{2}{|l|}{ Method: } & \multicolumn{3}{|c|}{ Least Squares } \\
\hline \multicolumn{2}{|c|}{ Sample(adjusted): } & \multicolumn{3}{|c|}{$1961: 1$} \\
\hline \multicolumn{2}{|c|}{ Included observations: } & \multicolumn{3}{|c|}{149 after adjusting endpoints } \\
\hline Variable & "Coefficient & Std. Error & t-Statistic & Prob. \\
\hline$\overline{\mathrm{UP}}$ & 0.009835 & 0.000828 & 111.87650 & $\overline{0.0000}$ \\
\hline DOWN & -0.013198 & 0.001131 & -11.66891 & 0.0000 \\
\hline \multicolumn{3}{|c|}{ R-squared 0} & \multicolumn{2}{|c|}{ 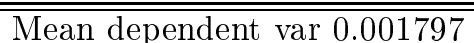 } \\
\hline \multicolumn{3}{|c|}{ Adjusted R-squared 0.645070} & \multicolumn{2}{|c|}{ S.D. dependent var 0.013690} \\
\hline \multicolumn{3}{|c|}{ S.E. of regression 0.008156} & \multicolumn{2}{|c|}{ Akaike info criterion -6.766748} \\
\hline \multicolumn{3}{|c|}{ Sum squared resid 0.009779} & \multicolumn{2}{|c|}{ Schwarz criterion -6.726427} \\
\hline \multicolumn{3}{|c|}{ Log likelihood 506.1227} & \multicolumn{2}{|c|}{ F-statistic 269.9835} \\
\hline \multicolumn{2}{|c|}{ Durbin-Watson stat 0.479834} & & \multicolumn{2}{|c|}{ Prob(F-statistic) 0.000000} \\
\hline
\end{tabular}

Table 1: Employment Development is Asymmetric

The Wald-Test shows at a significance level of less than $2 \%$ that $\left|\alpha_{1}\right| \neq\left|\alpha_{2}\right|$. Therefore we find an asymmetry between periods of positive and negative employment growth in Germany.

The same regression is also performed with employment data smoothed and de-trended by Hodrick-Prescott filtering (with a smoothing factor of 1.600 which is the default for quarterly data). The results are virtually the same:

\begin{tabular}{|c|c|c|c|c|}
\hline \multicolumn{2}{|c|}{ Dependent Variable: } & \multicolumn{3}{|l|}{ "GROWTH } \\
\hline \multicolumn{2}{|c|}{ Method: } & \multicolumn{3}{|c|}{ Least Squares } \\
\hline \multicolumn{2}{|c|}{ Sample(adjusted): } & \multirow{2}{*}{\multicolumn{3}{|c|}{$\begin{array}{c}1961: 1 \\
149 \text { after adjusting endpoints }\end{array}$}} \\
\hline \multicolumn{2}{|c|}{ Included observations: } & & & \\
\hline Variable & Coefficient & Std. Error & t-Statistic & Prob. \\
\hline$\overline{\mathrm{UP}}$ & 0.006099 & 0.000459 & 1313.28243 & 0.0000 \\
\hline DOWN & -0.004386 & 0.000536 & -8.176467 & 0.0000 \\
\hline \multicolumn{3}{|c|}{ R-squared 0.599982} & \multicolumn{2}{|c|}{ " Mean dependent var 0.001665} \\
\hline \multicolumn{3}{|c|}{ Adjusted R-squared 0.597261} & \multicolumn{2}{|c|}{ S.D.dependent var 0.006710} \\
\hline \multicolumn{3}{|c|}{ S.E. of regression 0.004258} & \multicolumn{2}{|c|}{ Akaike info criterion -8.066706} \\
\hline \multicolumn{3}{|c|}{ Sum squared resid 0.002665} & \multicolumn{2}{|c|}{ Schwarz criterion -8.026384} \\
\hline \multicolumn{3}{|c|}{ Log likelihood 602.9696} & \multicolumn{2}{|c|}{ F-statistic 220.4839} \\
\hline \multicolumn{3}{|c|}{ Durbin-Watson stat 0.268264} & \multicolumn{2}{|c|}{ Prob(F-statistic) 0.000000} \\
\hline
\end{tabular}

Table 2: Employment Development Asymmetries with Filtered Data

The Wald-Test shows at a significance level of less than $2 \%$ that $\left|\alpha_{1}\right| \neq\left|\alpha_{2}\right|$. Therefore we find also for the filtered data an asymmetry between periods of positive and negative employment growth in Germany.

From 1960 to 1998, we observe 4 periods with continuous employment increases and 4 periods with continuous employment decreases. If we calculate the 
average length of each period, we find $22 \frac{1}{4}$ quarters for upswings and $12 \frac{1}{4}$ quarters for downswings.

\section{References}

[1] Daron Acemoglu and Jörn-Steffen Pischke: "Beyond Becker: Training in Imperfect Labour Markets, "in: The Economic Journal, 109, pp. 112-142, 1999

[2] Gary Becker: "Human Capital," Chicago: University of Chicago Press, 2nd edition, 1975

[3] Olivier Blanchard and Lawrence Summers: "Hysteresis and the European Unemployment Problem," in: NBER Macroeconomic Annuals, Stanley Fischer (ed.), Cambridge, Mass.: MIT Press, pp. 23-78, 1986

[4] David Blanchflower: "Fear, Unemployment and Pay Flexibility" in: Economic Journal, pp. 483-496, 1991

[5] Simon Burgess: "Asymmetric Employment Cycles in Britain: Evidence and an Explanation", in: Economic Journal, 102, pp. 279-290, 1992

[6] Ricardo Caballero and Mohamad Hammour: "The Cleansing Effect of Recessions," in: American Economic Review, 84, pp. 1350-1368, 1994

[7] Andrew Clark and Andrew Oswald: "Unhappiness and Unemployment," in: The Economic Journal, 104, pp. 648-659, 1994

[8] William Darity and Arthur Goldsmith: "Social Psychology, Unemployment and Macroeconomics," in: Journal of Economic Perspectives, 10, pp. 121140,1996

[9] Wolfgang Franz: "Hysteresis in Economic Relationships: An Overview, "in: Hysteresis Effects in Economic Models," Wolfgang Franz (ed.), Heidelberg: Physica-Verlag, 1990

[10] Arthur Goldsmith and William Darity: "Social Psychology, Unemployment Exposure and Equilibrium Unemployment," in: Journal of Economic Psychology, 13, pp. 449-471, 1992

[11] S. Hargreaves Heap: "Choosing the Wrong 'Natural' Rate: Accelerating Inflation or Decelerating Employment and Growth?, "in: The Economic Journal, 90, pp. 611-620, 1980

[12] Jürgen Hauschildt: "Innovationsmanagement," Vahlen: München, 1993 
[13] Assar Lindbeck and Dennis Snower: "Wage Setting, Unemployement, and Insider-Outsider Relations," in: American Economic Review, 76 pp. 235239,1986

[14] Joachim Möller: "Unemployment and Deterioration of Human Capital,", in: "Hysteresis Effects in Economic Models", Wolfgang Franz (ed.), Heidelberg: Physica-Verlag, 1990

[15] Christopher Pissarides: "Loss of Skill During Unemployment and the Persistence of Employment Shocks," in: Quarterly Journal of Economics, 107, pp. 1371-1391, 1992

[16] David Ulph: "Dynamic Competition for Market Share and the Failure of the Market for Skilled Labour," in Alison Booth and Dennis Snower (eds.): "Acquiring Skills," , Cambridge University Press, Cambridge, pp. 81-108, 1996

[17] Rudolf Winter-Ebmer: "Persistenz von Arbeitslosigkeit", Frankfurt: Campus, 1992 